\title{
Use of green tea polyphenols in ameliorates cadmiumsulfate toxic effectson Wisterrat's female reproductive system
}

\author{
Sa'adeya Ali Al-Gnami And ZainabIbrahim AL-Lebawi \\ Al-Qadisiyauniversity/Collage of veterinarymedicine/ Department of Pharmacy/Iraq
}

\begin{abstract}
In recent years, green tea has become a subject of interest because of beneficial effects on human health The purpose of the present study was to investigate the effects of daily oral administration of green tea polyphenols for 30 days on plasma FSH and LH hormones and tissues of uterus and ovary in Wister rat's that treated with cadmium sulfate to show the preventive and curative effects of green tea polyphenols.

This experimental was carried out in animal hospital of veterinary medicine in Al-Qadisiya university. Twenty four of animals from female rats were used the animals were divided to four groups(six animal/group) which are control group (given water and food only) and three of treatment groups, the first treatment group was given $50 \mathrm{mg} / \mathrm{L}$ from cadmium sulfate with drinking water, the second treatment group was given cadmium sulfate $(50 \mathrm{mg} / \mathrm{L})$ and $400 \mathrm{mg} / \mathrm{kg}$ of $B . W$ from polyphenols, and the third treatment group was given polyphenols only $(400 \mathrm{mg} / \mathrm{kg}$ of B.W) the drenching was lasting for thirty days for all groups, all groups housed under same condition. The level of FSH and LH were measured in plasma. Thehistological sections of uterus and ovary were examined.

The results of this study revealeda significant decrease $(P \leq 0.5)$ in level ofFSH and LH in first treatment group that was drenched cadmium sulfate compare with control group, also the histological study was indicate damage in ovary and uterustissue. while, in second treatment group that was given polyphenols and cadmium sulfate the result shown to improve in ovary and uterus tissues and significant increase $(P \leq 0.05)$ in level of FSH and LH in compare with first treatment group and the results of this study indicated a significant increase $(P \leq 0.05)$ in FSH and LH in third treatment group that was given polyphenols only compare with other groups.
\end{abstract}

Key word:green tea ,polyphenol, cadmium sulfate, ovary, uterus ,FSH, LH.

\section{Introduction}

Cadmium is one environmental pollutants arising from electroplating,fertilizer,pigment and plastic manufactures therefore it easily contaminates the soil,plants,air and water(1).Cadmium in tobacco represent a contributory source to the total body burden of the smoker(2,3).Humans and animals can easily be exposed to cadmium toxicity by consuming plants, water and air.Cadmium is absorbed and accumulates in various tissue $(4,5)$ even red blood cells $(6)$ the heart $(7)$ and the skeletal muscle of rate(8).

Toxic effects reported with chronic exposure to cadmium include kidney damage (9),retardation of growth and hepatic damage (10),inhibition of drug metabolizing enzymes (11),CNS damage(12),reduced pancreatic secretary activity (13),renal dysfunction and hypertension (14)arteriosclerosis and cardiac disease (15).It caused a poisoning in various tissue of humans and animals. Acute administration of cadmium often induces lethal toxicityinmiceand $\operatorname{rats}(16)$.

The polyphenols a large group of plant chemicals that includes the catechins,are thought to be responsible for the health benefits that have traditionally been attributed to tea, especially green tea (17).The active components of tea responsible for such biological activities are now recognized to be catechins (also known as polyphenols) (18).Major catechins are epicatechin gallate (ECG), epicatechin (EC), epigallocatechin (EGC) , and epigallocatechingallate(EGCG).The most active and abundant catechin in green tea is epicallocatechin -3-gallate (EGCG)(19).

The purpose of the present study was to investigate the effects of daily oral administration of green tea polyphenols for 30 days on plasma FSH and LH hormones and tissues of uterus and ovary in Wister rat's that treated with cadmium sulfate to show the preventive and curative effects of green tea polyphenols.

\section{Extraction of phenolic compound}

\section{Material and Methods}

The leafs of green tea was obtained from local market of Al-Qadisyia city. Then dried and powdered, according to Gayon method(20).(200)gm of plant powder was weighted and added to (800)ml of $2 \%$ acetic acid and extracted, the mixture was left for 42 hours in an incubator at (50)co then filtered through filter paper to 
remove all the residual materials. The clear extracted solution treated with the same volumes of propanol and then saturated with Nacl. The upper layer was separated by funnel, then dried at $45 \mathrm{c}^{\circ}$ using an incubator.

\section{Experimental animals}

Twenty-four female Albino rats of Wister strain of age(6-8 weeks) and weighting about (250 \pm 13$) \mathrm{gm}$. were used for the experiment. These animals reared under controlled conditions. The period of this experimental was 30 days.

\section{Experimental design}

Animals were divided into four groups of six animals for each group:

1 - Control group :given distilled water for 30 days.

2- The first treatment group (T1) given $(50 \mathrm{mg} / \mathrm{L})$ of cadmium sulfatewith drinking water for 30 days

3- The second treatment group (T2) given $(50 \mathrm{mg} / \mathrm{L})$ of cadmium sulfate with drinking water, and orallygavage $(400 \mathrm{mg} / \mathrm{kg}$ of B.W $)$ of polyphenol for 30 days.

4- The third treatment group (T3) orally gavage ( $400 \mathrm{mg} / \mathrm{kg}$ of B.W) of polyphenol for 30 day.

\section{Blood and tissue collection}

At the end of the experimental period (30 days), the animals were sacrificed and blood samples were collected directly into tubes and centrifuged at $300 \mathrm{rpm}$ for 20 minutes. The obtained serum was stored at $4 \mathrm{c}^{\circ}$ for estimation of FSH and LH. The ovary and uterus was also quickly removed and washed with cold normal saline, cut and preserved in $10 \%$ neutral Formalin for the pathological studies for microscopy.

\section{Estimation of FSH and LH}

FSH and LHwere estimated according to method Radioimmunoassay(RIA) by using kit(21).

\section{Histological examinations}

Ovary and uterus tissues were cut in small pieces, placed in plastic cassettes, and immersed in neutral buffered Formalin for 24 hours. The fixed tissues were processed routinely, embedded in paraffin, sectioned, deparaffinized and rehydrated using the standard techniques(22).

\section{Statistical Analysis}

The one way analysis of variance(ANOVA) was used for analysis of study results, and then Duncan's test $(\mathrm{P} \leq 0.05)$ was detected to compare between groups (23).

\section{Results and Discussion}

The results obtained from this study showed a significantdecrease $(\mathrm{P} \leq 0.05)$ in $\mathrm{FSH}(4.466 \pm 0.918)$ and $\mathrm{LH}(0.311 \pm 0.186)$ hormones (table1) in first treatment group (T1) that was administrated cadmium sulfate(50 $\mathrm{mg} / \mathrm{L})$ in contrast with control group, also this study revealed a significant increase( $\mathrm{p} \leq$ $0.05)$ inFSH $(8.766 \pm 0.217)$ andnon significant increase $(\mathrm{P} \geq 0.05)$ in $\mathrm{LH}(0.633 \pm 0.049)$ in second treatment group (T2) that was administrated polyphenol $(400 \mathrm{mg} / \mathrm{kg}$ of B.W) and cadmium sulfate $(50 \mathrm{mg} / \mathrm{L})$ comparing with first treatment group (T1). Also, this study seems to show a significant increase $(\mathrm{p} \leq 0.05)$ in FSH $(15.083 \pm 0.562)$ and LH $(2.8 \pm 0.253)$ in third treatment group (T3) that was administrated polyphenols comparing with control group and second treatment group(T2)(table 1).

The histological study for ovary tissue of first treatment group showedsever necrosis within the ovarian stroma ,also there is sever suppression in the ovulation characterized by few and non-developed ovarian follicles with presence of corpus leuteum, Also there is sever congestion in the ovarian tissue ( figure 4,5 ).there is thrombosis within the ovarian stroma also there is non-developed primary ovarian follicle with presence of corpus leuteum (figure 6 ) in compare with control group (figure 1,2,3). ). The histological study for ovary tissue of second treatment group showed Higher magnification, Noted presence of mature gravian follicle (contain ova, theca interna and theca externa)(figure7) in compare with first treatment group. While, in third treatment group the results indicatedwave from follicular growth characterized by presence of mature gravian follicle (contain ova),secondary and primary follicles with corpus leuteum (figure10,11). The histological study for uterus of first treatment group indicated There is hyperplasia of uterine epithelium with small and nondeveloped uterine glands with infiltration of inflammatory cells(figure 14,15),alsoNoted thick wall of uterus tissue(figure 16)in compare with control group(figure 12,13). Also there is improved in uterus tissue of second treatment group ,it observed there is normal columnar epithelium which lining the uterine tissue, thick uterine wall also there is numerous and developed uterine glands(figure 17,18,19).Also this study indicated normalcolumnar epithelial which lining the uterine tissue,large-well developed uterine gland,and thickening of uterine wall in third treatment group(figure20,21). 
The recent studies have shown thatexposure of animals to cadmium induced oxidative stress stimulatesthe synthesis of cadmium binding proteins metallothioneins (MT) and heat proteins (24).Cadmiuminduced oxidative stress has been associated with production of reactive oxygen species (ROS) comprising mainly superoxide radical anion $\left(\mathrm{O}_{2}\right)$,hydrogen peroxide and hydroxyl radical $(\mathrm{OH})$ which lead to lipid peroxidation, membrane protein and DNA damage which can also result in carcinogenesis (25). And these free radicals cause the stimulation and destruction of sensitive macromolecular and indeed tissues(26) This had been reported to cause apoptosis, necrosis and cell proliferation $(27,28)$. Different studies have shown that cadmium affects plasma gonadotropin level(29). (30),reported that lead and cadmium are known as reproductive toxins, which accumulate in granulose cells of the ovary and cause a significant reduction in gonadotropin binding which altered steroidogenic enzyme activity of these cells. Also some studies indicated that cadmium may interfere directly with hormone production in steroid producing ovary cells(31). Also saw cadmium has deteriorating effects on the reproduction of women who live near the polluted area (32).Cadmium also directly cause destruction to the hypothalamus-pituitary-gonadal axis (33).In this study cadmium sulfate, inhibition of the serum hormonal levels of FSH and LH and causes damage in tissues of ovary and uterus ,all these changes may be returned to role of cadmium sulfate to release of free oxygen radicals that causes destruction of ovary and uterus tissues that is lead to decrease of FSH and LH hormones in serum or via directly effect of cadmium sulfate on the hypothalamus-pituitary-gonadal axis.

Polyphenols are known to be protective anti-oxidant they cause the inhibition of peroxidation , mopping up of free oxygen radicals and disorganization and breakage of peroxidation chain reactions $(34,35)$.Intake of green tea polyphenol increase the activity of superoxide dismutase in serum and the expression of catalase in the aorta; these enzymes are implicated in cellular protection against reactive oxygen species(36,37).therefore, the improving in ovary and uterus tissues and increase the level of FSH and LH in treatment group that administrated polyphenol returned to the important role of polyphenol as antioxidant agent .Also increase level of FSH and LH may be due to the ability of polyphenols for stimulation of it's synthesis from pituitary gland.

Table(1) effect of polyphenol on FSH and LH level of female Wister rats treated with cadmium sulfate

\begin{tabular}{|c|c|c|}
\hline Group & FSH & $\mathbf{L H}$ \\
\hline Control & $12.85 \pm 0.228^{A}$ & $2.35 \pm 0.334^{\mathrm{A}}$ \\
\hline $\begin{array}{l}\text { First Treatment } \\
\text { (T1) }\end{array}$ & $4.466 \pm 0.918^{B}$ & $0.311 \pm 0.186^{B}$ \\
\hline $\begin{array}{l}\text { Second Treatment } \\
\text { (T2) }\end{array}$ & $8.766 \pm 0.217^{C}$ & $0.633 \pm 0.049^{B}$ \\
\hline $\begin{array}{l}\text { Third treatment } \\
\text { (T3) }\end{array}$ & $15.083 \pm 0.562^{D}$ & $2.8 \pm 0.253^{A}$ \\
\hline
\end{tabular}

Number $=$ average \pm standard error (S.E)

Different litters $=$ significant differences $(\mathrm{P} \leq \mathbf{0 . 0 5})$

T1=given cadmium sulfate $(50 \mathrm{mg} / \mathrm{L})$ with drinking water for 30 day

$\mathrm{T} 2=$ given cadmium sulfate $(50 \mathrm{mg} / \mathrm{L})$ with drinking water and orally gavage polyphenol $(400 \mathrm{mg} / \mathrm{Kg} \mathrm{of}$

B.W)for 30 day

$\mathrm{T3}=$ orally gavage polyphenol $(400 \mathrm{mg} / \mathrm{Kg}$ of $\mathrm{B} . \mathrm{W})$ for $30 \mathrm{day}$. 


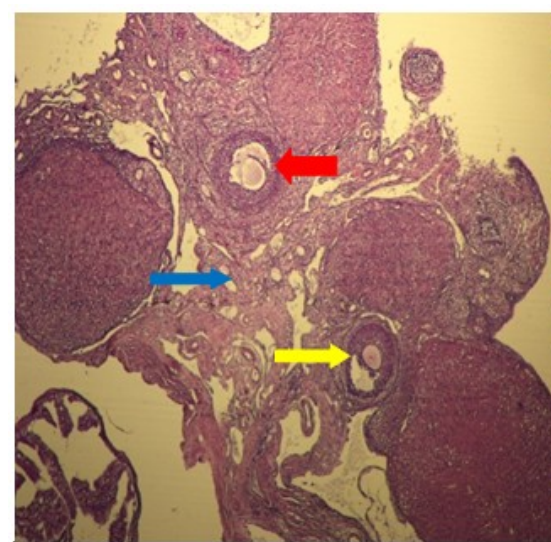

Figure(1):Ovary of control group: presence of primary(red arrow) and secondary follicles(yellow arrow( with corpus leutum(blue arrow). 20X H\&E.

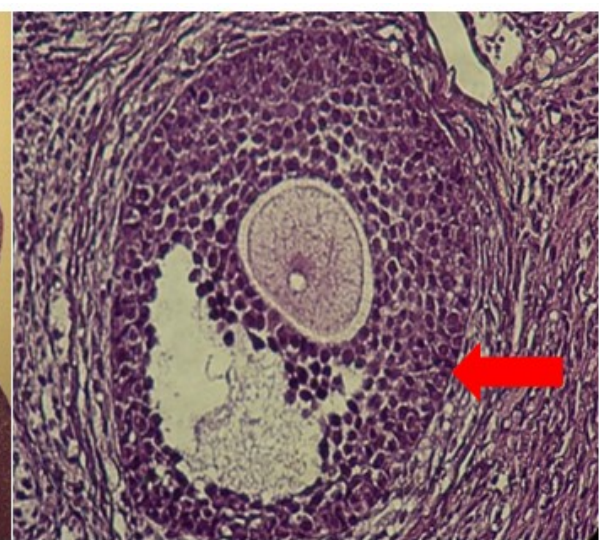

Figure (2): Ovary of control group: Presence of gravian follicles (which contain ova, theca interna and theca externa )(red arrow). $200 \mathrm{X}$ $\mathrm{H} \& \mathrm{E}$.

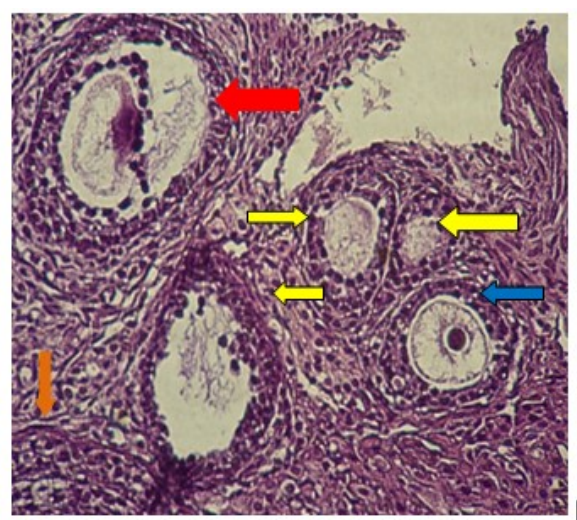

Figure (3): Ovary of control group: Presence of gravian follicles (which contain ova theca interna and theca externa) (red arrow).Also there are primary(yellow arrow) and secondary follicles(blue arrow) with corpus leutum(orange arrow). 50X $\mathrm{H} \& \mathrm{E}$.

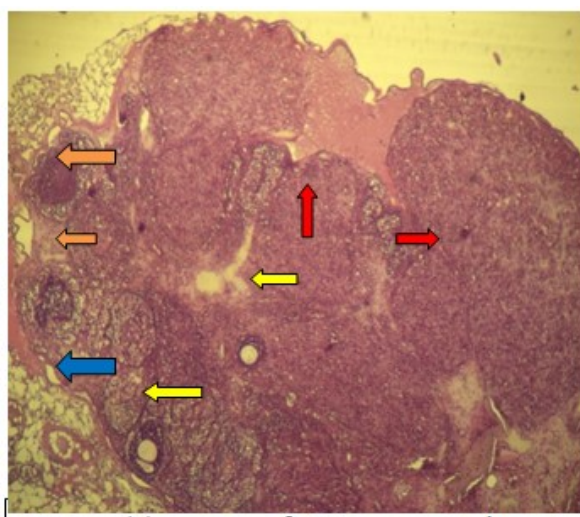

Figure (4): ovary of T1 group: There is sever necrosis within the ovarian stroma(red arrow), also there is sever suppression in the ovulation characterized by few and nondeveloped ovarian follicles(yellow arrow) with presence of corpus leutum(orange arrow). Also there is sever congestion in the ovarian tissue(blue arrow). $20 \mathrm{X} \mathrm{H} \& \mathrm{E}$.

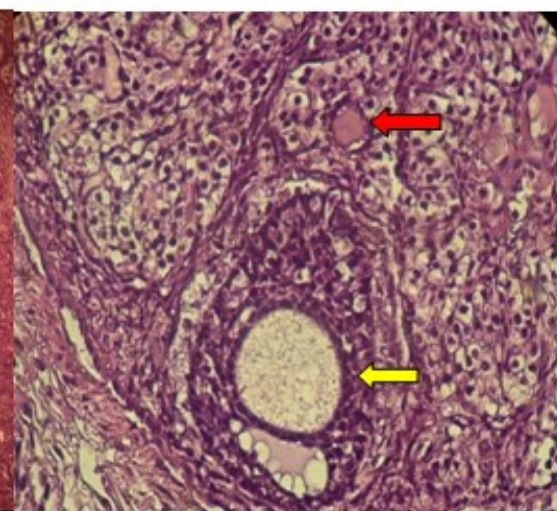

Figure (6): Ovary of T1 group there is thrombosiswithin the ovarian stroma(red arrow) also there is nondevelopedprimaryovarian

follicle(yellow arrow) with presence of corpus leutum. 50X H\&E. there is sever congestion in the ovarian tissue(blue arrow). 20X H\&E. 


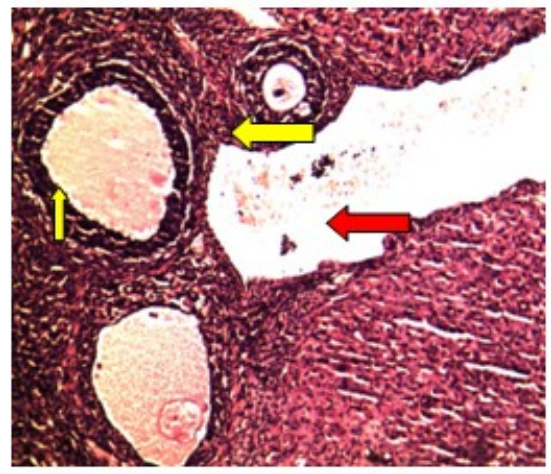

Figure (7): Ovary of T2 group: There is secondary (red arrow) and primary follicles in the ovarian stroma.

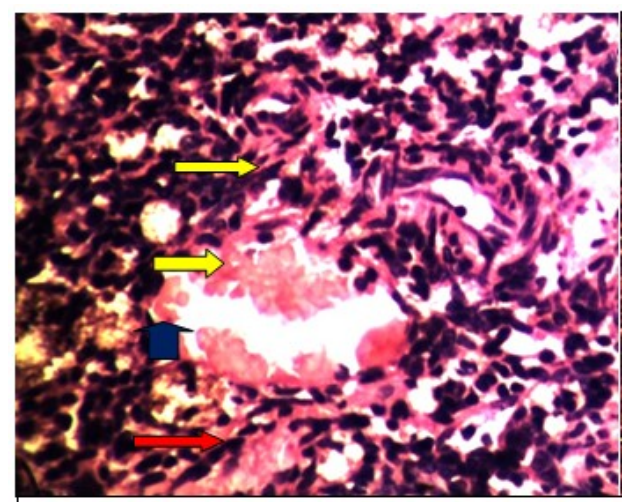

Figure (8): Ovary of T2 group: There is mild congestion (red arrow) with normal follicular growth , there is secondary (yellow arrow) and primary follicle(blue arrow) $.50 \mathrm{xH} \& \mathrm{E}$.

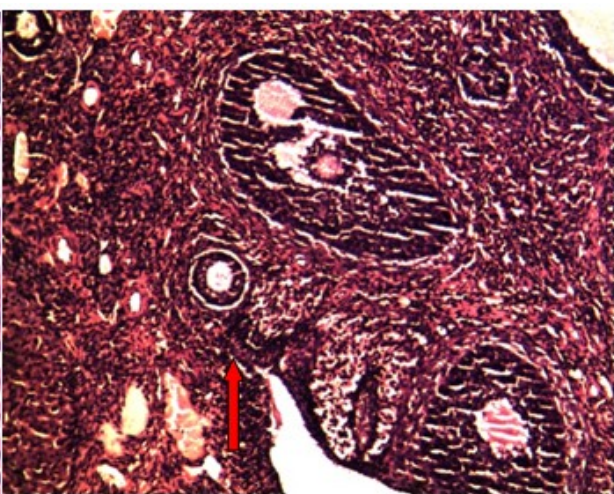

Figure (9): Ovary of T2 group: higher magnification, there is congestion in the ovarian stroma(red arrow). $200 \times \mathrm{xH} \& \mathrm{E}$

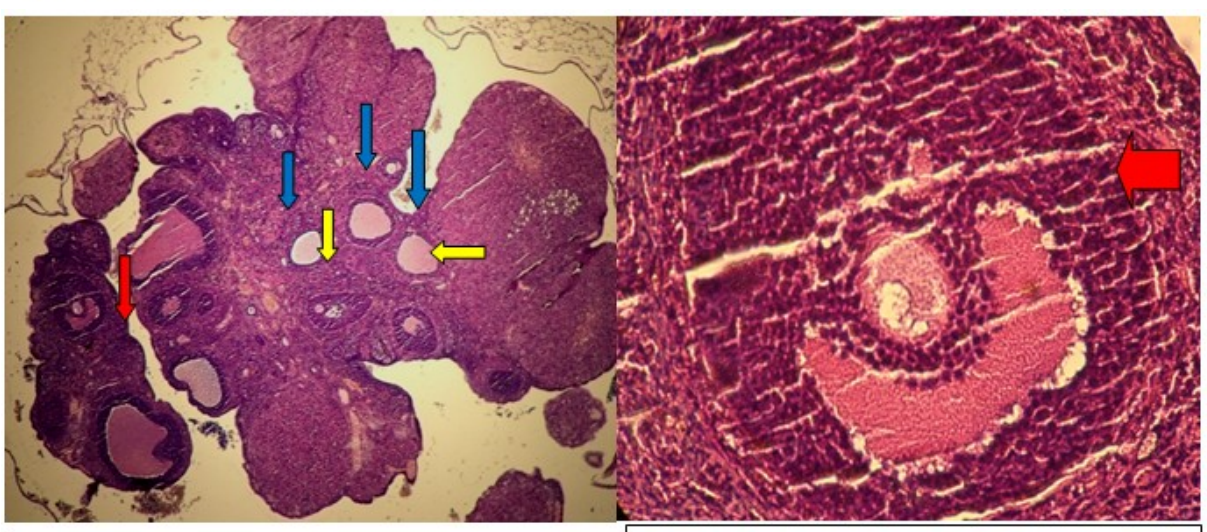

Figure (10): Ovary of T3 group : Note wave from follicular growth characterized by presence of mature gravian follicle (contain ova(red arrow)),secondary(yellow arrow) and primary(blue arrow) follicles with corpus leutum. 20X H\&E.
Figure (11): Ovary of T3 group : Higher magnification .Note presence of mature gravian follicle (contain ova theca interna and theca externa)(red arrow) $200 \mathrm{xH} \& \mathrm{E}$. 


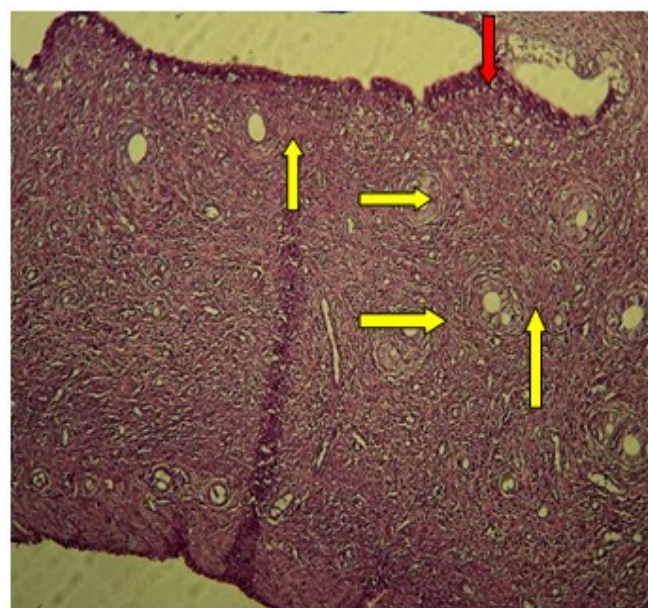

Figure(12):uterusof control group:there is normal uterine epithelium(red arrow), and large developed uterine glands(yellow arrow). 20X H\&E.

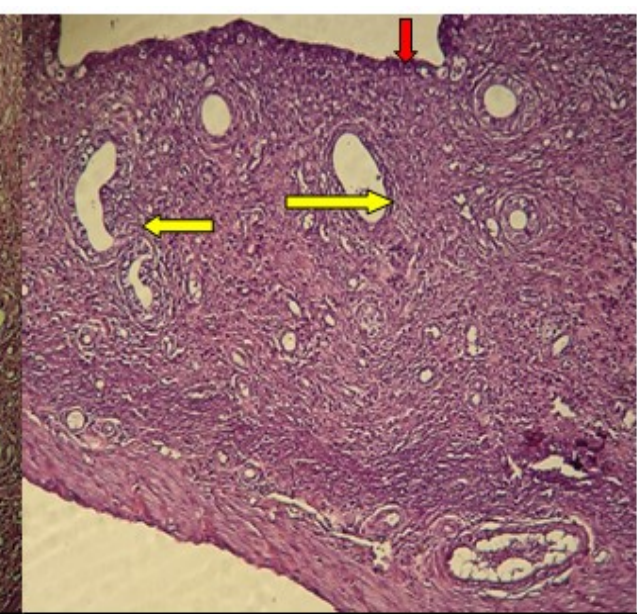

Figure (13): uterus of control group: there is normal uterine epithelium(red arrow), and large developed uterine glands(yellow arrow). 50X H\&E.

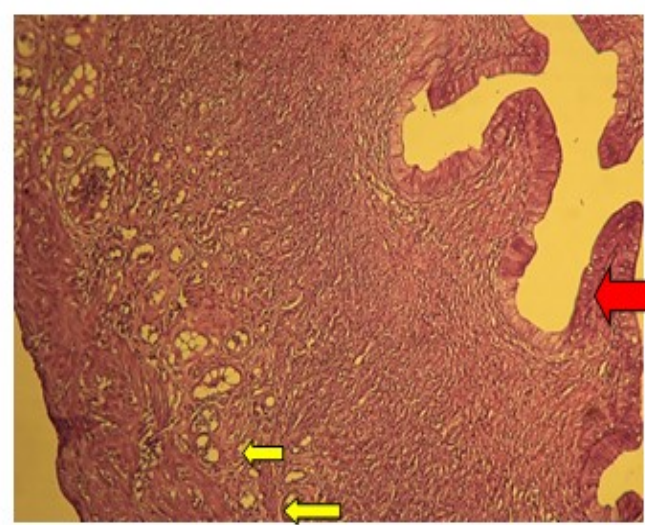

Figure (14): uterus of T1 group: There is hyperplasia of uterine epithelium (red arrow) with small and non-developed uterine glands (yellow arrow) with infiltration of inflammatory cells. 50X $\mathrm{H} \& \mathrm{E}$.

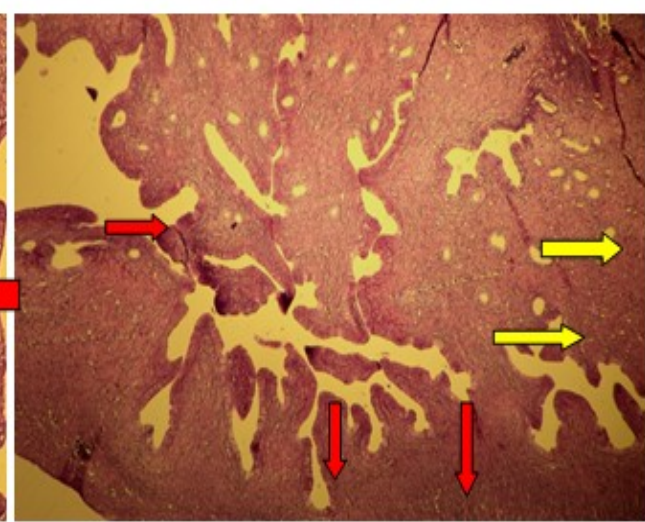

Figure (15): uterus of T1 group: there is hyperplasia of the uterine epithelium (red arrows) with small and nondeveloped uterine glands (yellow arrows). 20X H\&E. 

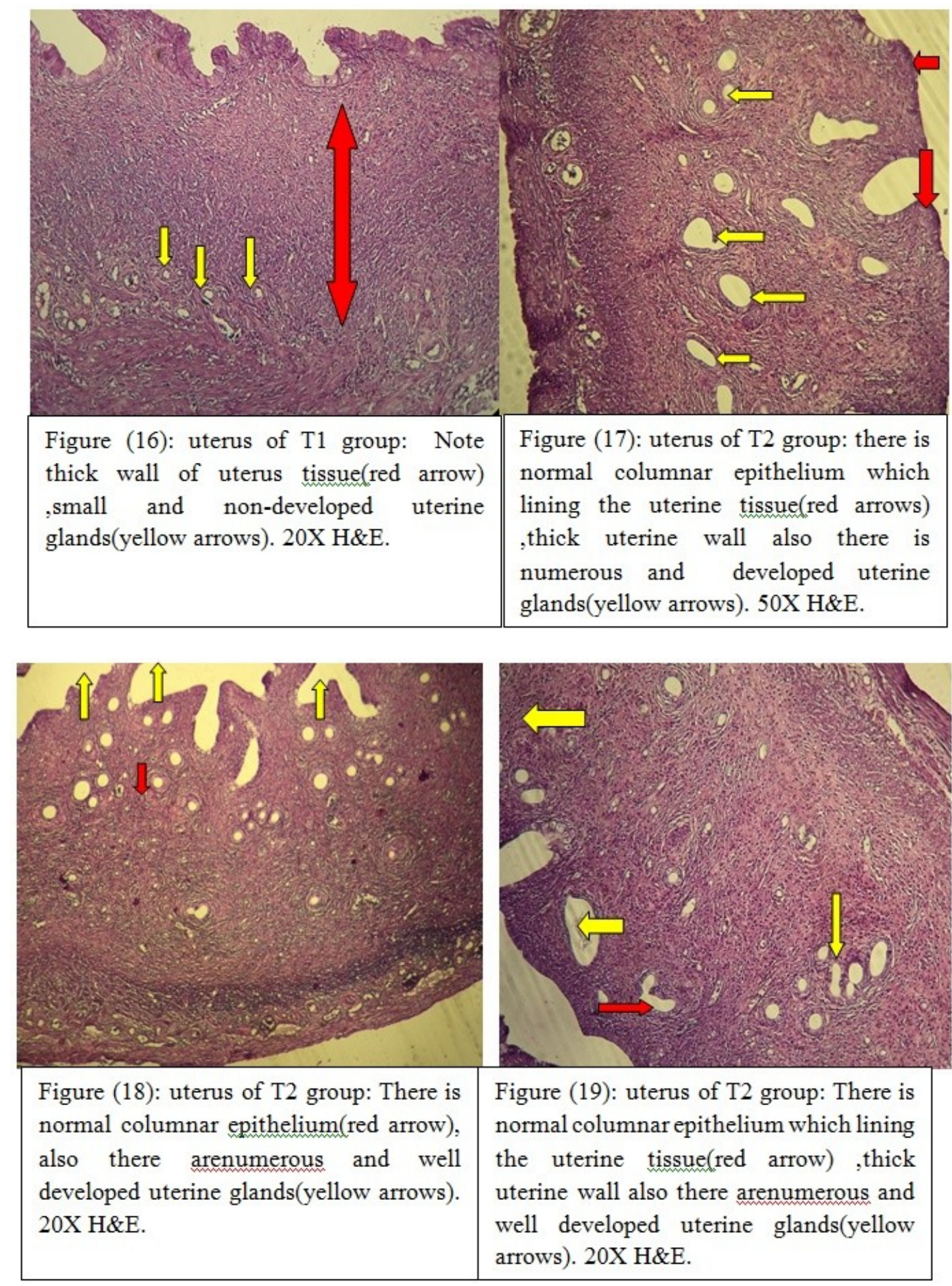


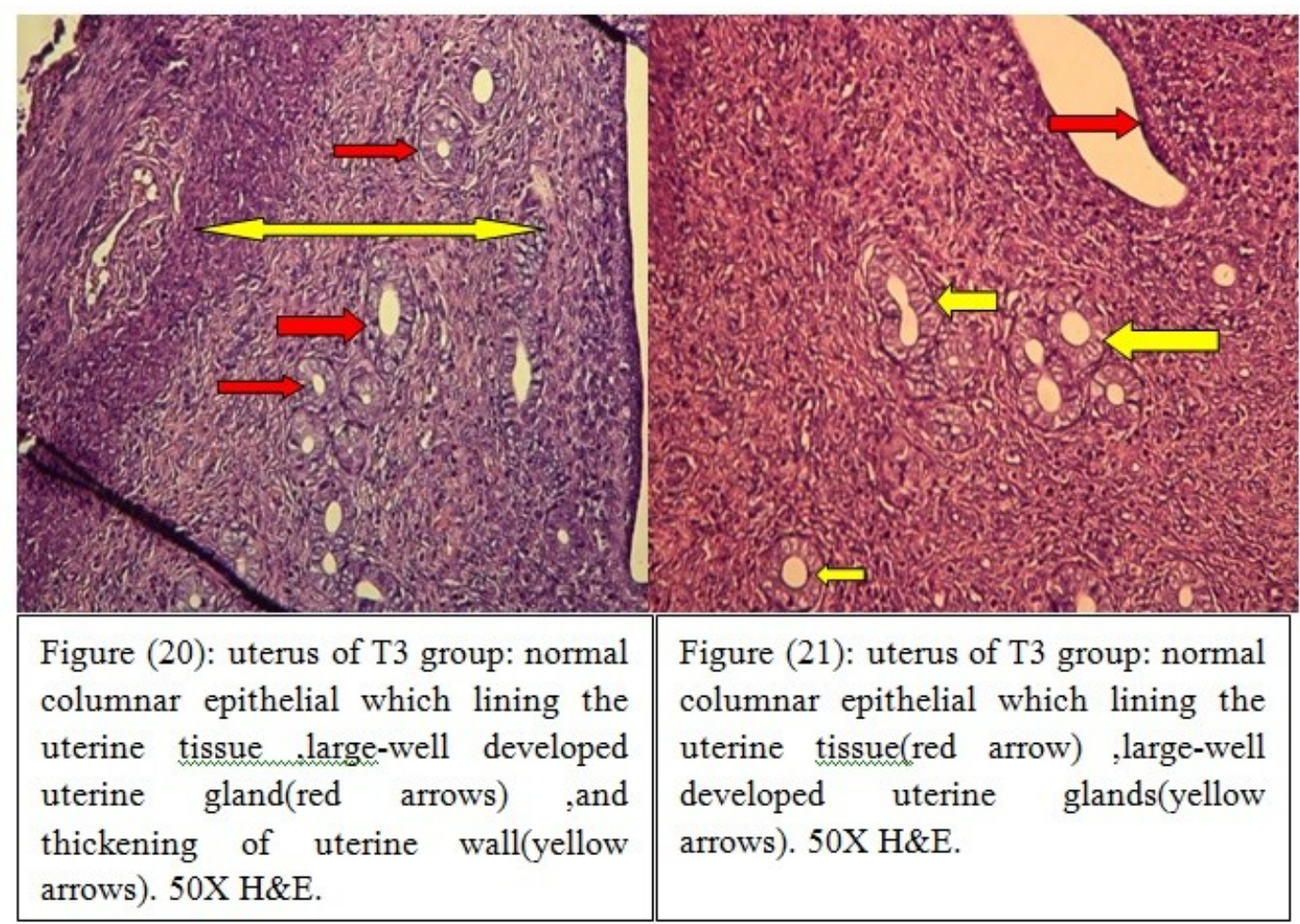

\section{References}

[1]. Ognjanovic,B.I.;Markovic,S.D.;Pavlovic,S.Z.;Zikic ,R.V.;Stajn,A.S. and Saicic, Z.S.(2008).Effect of chronic cadmium exposure on antioxidant defense system in some tissue of rats:Protictive effect of selenium physiol .Res.57:4O3-411.

[2]. Schroeder ,H.A.;Balassa ,j.J.;hogencamp,j.c.(1961).Abnormal trace metals in man.Cadmium .J.chronic Dis .14,236-58

[3]. Lewis ,G.P.;Jusko,W.J.;Coughlin, L.L.;Hrtz,S.,(1972).Contribution of cigarette smoking to cadmium accumulation in man .lancet .1(7745):291-292.

[4]. Casalion,E.;Calzaretti,G.;Sblano,C. and Landriscina, C.(2002).Molecular inhibitory mechanisms of antioxidant enzymes in rat liver and kidney by cadmium .Toxicology.179:37-50

[5]. Weisbeg,E.(1985).Smoking and reproductive health.Clin.Reprod.Afr.J .Biotechnol.Fertil.3:175-186.

[6]. Kostic M.M.;Ognjanovic B.;Dimitrijevic S.;Zikic R.V.;Stajn A.;Rosic G.L.(1993). Cadmium-induced changes of antioxidant and metabolic status in red blood cells of rat:In vivo effects .Eur.J.Haematol 51:86-92.

[7]. Zikic ,R.V.; Stajn,A.S.;Ognjanovic,B.I.;Saicic,Z.S.;Kostic,M.M.;Pavlovic,S.Z. and Petrovic,V.M.(1998). The effect of cadmium and selenium on the antioxidant enzyme activities in rat heart.J.Environ Pathol. Toxicol .Oncol.,17:259-264.

[8]. Pavlovic ,S.Z.;Onganovic,B.I.;Stajn,A.S.;Zikic ,R.V.;Saicic,Z.S.; Petrovic,V.M.(2001).Antioxidant defense system in skeletal muscle of rats treated with cadmium .A possible protective role of coenzymeQ 10 .Jugoslav.Med.Biochem.,20;229-235.

[9]. Axelson, B.;Riscator,M.(1966).Renal damage after prolonged exposure to cadmium .Arch Env Health 12;360-376.

[10]. Smith ,J.; Smith,PJC.; Macall,AJ.(1960).Chronic poisoning from cadmium fumes .J. Path Bact 89;287-269.

[11]. Gablioni,G.(1966).Action of cadmium chloride on sensory ganglia .EXP22;261-262.

[12]. Gabjioni,G.(1967).Cadmium-induced selectivity lesion of sensory ganglia .J Neuropath ExpNeurol 26;498-550.

[13]. Ghafghazi,T.;Mennerar,J.H.(1973).Effect of acute and sub acute cadmium administration on carbohydrate metabolism in mice ToxicolApplPhrmacol 26;231-240.

[14]. Schroeder,H.A.(1968).Action of chelate of zinc on trace metals in hypertensive rats.Am J.Physiol 214;769-800

[15]. Tuker,A.(1972). The toxic metals.New York,Ballantine books, 1-6.

[16]. Jung,D.;Yaping ,L.andCurtis,D.(2001).Protective effect of metallothionein against the toxicity of cadmium and other metals.Department of pharmacology,Toxicology,\&Therapeutics,Univecity of Kansas Medical Center,USA.Toxicology.163:93-100 .

[17]. Cabrera,C.; Artacho,R. and Gimenez,R.(2006).Beneficial effects of green tea a review.J.Am.Coll.Nutr.,25(2):79-99.

[18]. Yoko,Y.;Yoshimasa,Y.; Yukihiko,H.andTadakatsu,S.(2003).Acombintion effect of green tea catechins, with antibiotics on Helicobacter pylori growth in vitro.Current Microbiology, an International J.47:244-49.

[19]. Wu,A.H. and Yu,M.C.(2006).Tea hormone-related cancers and endogenous hormone levels. Mol.Nutr.Food Res.,50(2):160-169.

[20]. Gayon,T.A. ( 1972 ). Plant phenolic . Olive and Boyed . Rd In boura .pp 254.

[21]. Berga, S.L.and Daniels, T. L. (1991). Use of laboratory in disorder of reproductive neuroendocrinology.J.Clin.Immunossay,14:2338.

[22]. Luna , L . G . (1968). Processing of tissue, histologic staining methods of the aimed forces institute of pathology . 3rdEd .McGraw Hill book comp .London, New York, Toronto, Sydney . pp : $12-31$.

[23]. Shiefler, W . C. (1980) ). Statistics for biology science .2nd Edition. Adison, Wesley, Pub . co . London Amsterdam . pp. 121

[24]. Klaasse,C.D. ;Liu,J. and Choudhuri, S.(1999).Metallothionein: an intracellular protein to protect against cadmium toxicity.AnnuRev PharmacolToxicol,39:267-294.

[25]. Bagchi,D.;Bagchi,M.;Hassoun,E.Stohs,S.J.(1996).Cadmium-induced excretion of urinary lipid metabolites,DNAdamage,glutthion depletion and hepatic lipid peroxidation in Sprague-Daweley rats. Biol.Trace. Element.Res.52:143-154.

[26]. Lafuente, A. ;Marquez,N. ; Perez-Lorenzo,M.;Pazo, D. and Esquifino, A.I.(2000).Pubertal and postpubertal cadmium exposure differentially affects the hypothalamicpitutary-testicular axis function in the rat Food ChemToxicol. 38:913-923.

[27]. Habbeebu,S.S ;Lui,J. and Klaassen,C.D.(1998).Cadmium-induced apoptosis in mouse liver.ToxicolApplPharmacol 149(2):203-209. 
[28]. stohs,S.J.; Bagchi,D.Hssson,E. and Bagchi,M.(2001).Oxidative mechanisms in the toxicity of chromium and cadmium ions. J.Environ.Pathol.Toxicol.Oncol.,20:77-88.

[29]. Lafuente,A.;Blanco,A.;Marquez,N.;Alvarez-Demanuel,E.Esquifino ,A.(1997). Effect of acute and subchronic cadmium administration on pituitary hormone secretion in rat.RevEsp Fisiol.53:265-270.

[30]. Nampoothiri,L.P. and Gupta,S.(2005).Simulataneous effect of lead and cadmium on granulose cells:A cellular model for ovarian toxicity. Reproductive Toxicology, 21(2):179-85.

[31]. Piasek,M.andLaskey,J.W.(1999).Effect of in vitro cadmium exposure on ovarian steroidogenesis in rats. Journal of Applied Toxicology, 19(3):211-7.

[32]. Wu,S.Y.;Tian,J.;Wang,M.Z.,Pan,B.J.;Lu,H.D.Wang,Z.M.andLi,H.Y.(2004).The effect of cadmium pollution on reproductive health in females.Zhonghua Liu Xing Xue Zhi,25(10):852-5.

[33]. assanyi,P.;Lukac,N.;Slivkova,J.;Kovacik,J.;Makarevich,a.V.;Chrenek,P;Toman,R.;Forgacs,Z.;Somoosy,Z.;Stawarz,R.;Formicki,G.( 2007).Mercury-induced alterations in rat kidneys and testes in vivo.J Environ Sci Health A Tox Hazard Subst Environ Eng.Jun;42(7):865-870.

[34]. Williams , R . J . ; Spencer, J . P ., and Rice - Evans , C . (2004 ). Flavonoid :antioxidants or signaling molecules . free radical biology and medicine 36(7) : 838-49-doi : 10 . $1016 \mathrm{~J}$.freeradbiomed .

[35]. Felicien , B . (2008) Polyphenol antioxidants in red win ( http : / www . French scout .com / polyphenols ) .

[36]. Negishi,H.;Xu,J.W.;Ikeda,K.;Njelekela,M.;Nara,Y.;andYamori,Y.(2004).Black and Green tea polyphenols attenuate blood pressure increases in stroke-prone spontaneously hypertensive rats.JNutr.134:38-42.

[37]. Skrzydlewska , E. Ostrowska ,J. ; Farbiszewski , R . ; andMichalak , K .

(2002) . Protective effect of green tea against lipid peroxidation in the rat liver blood serum and the brain phytomedicine $9: 232-238$ 